\title{
Research on Colleges' Internet Ideology and Politics Education Under the New Time
}

\author{
Lujun IV \\ Jilin Agricultural Science and Technology University, Jilin, 132101, China \\ email:Ivlujun0357@163.com
}

Keywords: virtual world, internet, ideology, politics, development

\begin{abstract}
Colleges and universities is the important base of training builders and successors for the socialist modernization. And university students are the main use of the Internet community. With the development of electronic technology and mobile communication technology in our country, the vast majority of college students can easily use the computer to the Internet, almost all of the college students are using mobile phone, mobile phone use on the Internet are now very common in colleges and universities. Internet brings students into a virtual world, in this virtual world.
\end{abstract}

\section{Introduction}

The rapid development of Internet technology has greatly changed people's life style and working way, it represents the trend of The Times, but also profoundly affects people's world now, the outlook on life and values.

The rapid development of Internet technology has greatly changed people's lifestyle and working way, [1]it represents the trend of The Times, but also profoundly affects people's world now, the outlook on life and values. Ideological and political education under the influence of the Internet is enjoying a good historical opportunity. Firstly, the thesis expatiates on the research background of this thesis, and explains the theoretical and practical significance of the education problem and countermeasure research in the network environment. On the basis of literature review, this paper puts forward the research ideas, research methods and possible innovation points of this paper. Then, the core concepts of this article "network environment", defined the concept of the network ideological and political education. It is pointed out that the network environment has the characteristics of virtual, interactive, open, dynamic, information dissemination, and management. [2]To sum up, we emphasized the method of education, the method of catching the truth, the way of thinking and the synchronization of the problem, the communication and communication method of "key pair bond and heart to heart".They can understand the culture of the countries all over the world. They can grasp the current world events. They can search to they want to know all kinds of knowledge. The network has brought new opportunities to ideological and political education work for development. Through the network, the content of the ideological and political education more rich, more modern and diversity means and ways, [3]form and content is more attractive, the effect is more obvious, and the ideological and political education workers are easier to understand the real ideological dynamic and psychological problems. But open, diverse network environment, good ideas about race not neat, unhealthy culture and the impact of western decadent culture, and the challenge of network into a tumor, also for college students' value orientation, political attitude, personality psychological aspects bring about many negative impacts. [4]With a small group of public opinion in campus network, campus network public opinion is also easy to induce the crisis event "fuse", to make ideological and political education work to appear more controllable, face more severe challenges.

Network ideological and political education in colleges and universities faces unprecedented challenges. Angle of view in the research is ideological and political education under the network environment problem and countermeasure research (Zhou, 2013). [5]Its pertinence is strongly guiding the significance to practical work. On the development trend of education of university ideology and politics under the network environment, the viewpoints of education "four 
modernizations" (individualization, socialization, pluralism, and rationalization) are relatively new (L. J. Li, 2016). [6] In strengthening the ideological and political education work under the network environment the countermeasure aspect, put forward the concept of "four education" (everything for the student's development idea, the education and ego education (Zhi, 2017). [7] The idea of combining, from closed to open principle, equal interaction and dredge the idea of combining) as well as each other heart "key on the key," working method has certain creativity (Wan, 2016). [8]

\section{The Connotation of Education of University Ideology and Politics Ender Network Environment}

For the concept of network environment, from the present research status and achievements, there are two main understandings, namely, broad and narrow sense. In a broad sense, network environment refers to the entire social environment under the network era. In the narrow sense, it refers to the socialized cyber space, i.e. a virtual environment (A. F. Chen \& Gao, 2016). [9]

$$
\nabla^{2}=\nabla_{r}^{2}+\frac{\partial^{2}}{\partial z^{2}}=\frac{\partial^{2}}{\partial r^{2}}+\frac{1}{r} \frac{\partial}{\partial r}+\frac{\partial^{2}}{\partial z^{2}}
$$

Virtual environment and real life environment is not completely the opposite, in the process of development of information technology, they presented a kind of contains and contained relationship, namely virtual environment has become an important constitute part of the real life environment (Liang \& Zheng, 2015). [10]The main elements that make up the network environment include network subjects, network information, network technology and infrastructure, and network policies and regulations and network culture. In order to make the research of this paper more targeted, the network environment referred to in this paper is mainly the virtual environment in the narrow sense (Long, 2015). [11]

$$
\phi=E_{0} \exp \left\{-i\left[p(z)+\frac{k}{2 q(z)} r^{2}\right]\right\}
$$

Network environment is along with the development of the era, is a new environment, it is contrary to natural environment and social environment, it has a virtual sex, interactivity, openness, vitality, information dissemination characteristics such as universality, management of autonomy. [12]

Based on virtual technology, the network environment is a virtual reality environment, which is different from real physical space (Wu, Wen, \& Wan, 2015). [13] Virtual reality is the most essential feature of the network environment. In network environment, the information such as age, gender, appearance, identity are not clear because of network. The content of the communication between people is also really also false. Everyone can take each other as their own need communication and understanding. In addition, based on the network platform, people cannot constrained by the space and time. People's practical activity is shifting from the physical space to the electronic space, communication between people become virtual.

$$
\nabla^{2} \phi-2 i k \phi^{\prime}-k k_{2} \phi r^{2}=0
$$

Interactive network environment refers to "people can always interactions in the network society, sending, transmission and receiving all kinds of multimedia information" (He, 2015) . Network has changed the past newspapers, magazines, radio, television and other media one-way transmission of information is limited, the information communication into interactive communication in a timely manner (G. H. Wang, 2015). People can always communicate with each other on a one-to-one basis, one-to-many, and multi-pairs. People are no longer passive recipients of information dissemination, but are all free who can choose themselves (Yan \& Ma, 2016).

\section{The Connotation of Education of University Ideoplogy and Politics}

According to the literature, there are two main viewpoints on the concept of "Internet ideology and politics education" (S. G. Chen, 2017). A view that the network ideological and political education refers to the ideological and political education based on network technology, people with these 
views the Internet as a carrier, tool or means to carry out ideological and political education ( $\mathrm{Li}$, Zhao, Tong, Wang, \& $\mathrm{Xu}, 2016)$. Another view is that the Internet ideology political education refers to the ideological and political education, which is based on the network environment, and the people who hold this view use the Internet as a education environment (L. Wang, 2016).

$$
\frac{1}{\mathrm{w}^{2}}=\frac{\pi}{\lambda} \frac{f}{f^{2}+\mathrm{z}^{2}}
$$

Among the definition of "network ideological and political education" concept, the author thinks that "network ideological and political education" concept generalization are more comprehensive (Liu \& Meng, 2016). That is, the network ideological and political education rely on computer and network technology, based on the cognitive characteristics of virtual society, network propagation and education method, moral and political ideas of educates information education form of assimilation The above two views on network ideology and politics education rely on two different perspectives, but also in the ideology politics education in colleges.

$$
U_{00}=\exp \left(-\frac{x^{2}+y^{2}}{\omega^{2}(z)}\right)
$$

In fact, as the education environment of the network is as education tool applied to generalization, the network of the day-to-day work of the results, and many aspects such as the daily study and life of college students connect with the network tightly, through the network to understand college students' ideology and value orientation, etc.

$$
I(r)=I_{0} \exp \left(-\frac{2 r^{2}}{\omega^{2}}\right)
$$

Therefore, the ideological and political education of universities in the new period must be network as the education environment, in this way, the ideological and political education is more targeted, also will produce actual results Differences from ideological \& political education in the network environment and that kind of education in universities in the real world. Networks are constantly changing the environment of college students, changing the way students' study, life, friends, affect college students' value orientation, behavior norms and ideology, speeding up the ideological and political education mode, method, means and contents of the reform (Wu, Liao, \& Chen, 2015).

$$
T=\frac{P_{\alpha}}{P_{\infty}}=\frac{\int_{0}^{\alpha} \int_{0}^{2 \pi} I(r) 2 \pi r d r d \theta}{\int_{0}^{\infty} \int_{0}^{2 \pi} I(r) 2 \pi r d r d \theta}=1-\exp \left(-\frac{2 \alpha^{2}}{\omega^{2}}\right)
$$

Under the network environment, the universities' ideological and political education opportunities and challenges coexist (W. X. Chen, 2013). Opportunities, such as network openness, fast speed, vivid, the content of the education than the traditional ideological and political education of richer and more diverse ways, means more advanced education, education forms more attractive, education effect is more obvious (Z. G. Wang, 2014).

$$
\frac{1}{q(z)}=\frac{1}{R(z)}-i \frac{\lambda}{\pi w^{2}(z)}
$$

For college students, the challenge is mainly from values, ethics, interpersonal communication and mental health (Yu, 2012; Zhang, 2016). For the ideological and political education work, is the education contents, ways, methods and means more demanding, the subject status of the ideological and political education, the quality of ideological and political education workers are facing severe challenges.

$$
q(\mathrm{z})=\mathrm{z}+\text { if }
$$

Profoundly realize the ideological and political education under the network environment facing the opportunities and challenges, and forecast its developing trend, for us to adapt to the new era, innovative working methods, explore effective way is of great significance and far-reaching. 


\section{Conclusion}

In the current, a very important job is to strengthen college students' network moral construction. We should combine instrumental rationality with value rationality, network technology development and humanistic spirit cultivation to make network morality the most solid foundation of network civilization. Colleges and universities should list the network moral education as the education content. At the same time, universities should carry out special topics such as "observe social morality, create network civilization", "use the Internet in accordance with law, and be civilized law-abiding netizens". In this way, college students are encouraged to build proper network moral concepts and cultivate good network ethics and become civilized people in the Internet era.

\section{References}

[1]Chen, A. F., \& Gao, J. (2016). Characteristics and Rules of College Students' Growth in APP Era-Investigation of Ideological and Political Education Under the Environment of Internet Plus. 2016 2nd International Conference on Humanity And Social Science (Ichss 2016), 247-252.

[2]Chen, S. G. (2017). Research on the Interactive Mode of Internet and Traditional Ideological and Political Education in Colleges and Universities. Agro Food Industry Hi-Tech, 28(1), 1089-1093.

[3]Chen, W. X. (2013). Innovation Research on College Ideological and Political Education Based on the Internet Interactive Mode. 2013 International Conference on Economic, Business Management And Education Innovation (Ebmei 2013), Vol 18, 18, 391-395.

[4]Du, Z. P., \& Xue, Y. J. (2016). Enhance the Effectiveness of University Ideological and Political Education based on "Internet plus ". Proceedings Of the 2016 4th International Education, Economics, Social Science, Arts, Sports And Management Engineering Conference (Ieesasm 2016), 22, 1184-1188.

[5]He, L. Z. (2015). The New Trends and Strategies of College Ideological and Political Education in Internet Age. Proceedings Of the International Conference on Education, Management And Information Technology, 35, 456-460.

[6]Li, L. J. (2016). Research on Innovation of Ideological and Political Education in the Internet Age. Proceedings Of 2016 5th International Conference on Social Science, Education And Humanities Research, 69, 811-815.

[7]Li, W., Zhao, K., Tong, X., Wang, H. H., \& Xu, M. (2016). The Path of College Ideological and Political Education Research in the Background of Mobile Internet. International Conference on Education And Development (Iced 2016), 264-269.

[8]Liang, L. H., \& Zheng, X. G. (2015). The Countermeasures Research of Ideological and Political Education Work in China Colleges and Universities in Internet Age. Proceedings Of the 2015 Conference on Informatization In Education, Management And Business, 20, 653-656.

[9]Wang, L. (2016). Research on the Ideological and Political Education Mode under the Internet and Media Era. Proceedings of the 2016 2nd International Conference on Economics, Management Engineering and Education Technology (ICEMEET 2016), 87, 725-728.

[10]Wang, Z. G. (2014). The Approaches to Enhancing Influence of the Theoretical Course of Ideological and Political Education in Colleges -From the Perspective of New Media through Internet. 2014 4th International Conference on Education And Education Management (Eem 2014), Pt 7, 69, 207-211.

[11]Wu, J., Liao, D. H., \& Chen, A. M. (2015). Research on the Effectiveness of the Ideological and Political Education for University Students under the Environment of Internet Technology. 
Proceedings Of the 2015 Conference on Informatization In Education, Management And Business, 20, 489-493.

[12]Yan, X. S., \& Ma, B. (2016). Research on the Developmental Trend of Education Pattern of the Contemporary College Students' Ideological and Political Education under the Background of Internet Era. Proceedings Of the 2016 2nd International Conference on Social Science And Technology Education (Icsste 2016), 55, 900-905.

[13]Yang, M., \& Wang, Y. (2016). Internet culture-a new way for ideological and political education of university students. Proceedings Of the 2016 2nd International Conference on Social Science And Technology Education (Icsste 2016), 55, 1045-1049. 